\title{
New species of Periclimenaeus Borradaile (Crustacea: Decapoda: Pontoniinae) from Ashmore Reef, North Western Australia, with remarks on P. pachydentatus Bruce, 1969
}

\author{
A.J. Bruce \\ Queensland Museum, P.O. Box 3300, South Brisbane, Queensland 4101, Australia \\ e-mail: abruce@broad.net.au
}

\begin{abstract}
Two new species of the pontoniine shrimp genus Periclimenaeus, from ascidian hosts from Ashmore Reef, Western Australia, are described and illustrated. Periclimenaeus kottae sp. nov., an associate of Didemnum membranaceum Sluiter, is one of the smallest pontoniine shrimps known. Periclimenaeus matherae sp. nov. is an associate of Hypodistoma deerata (Sluiter). Comparative figures are provided of $P$. pachydentatus Bruce, 1969, the range of which is extended to the Philippines.
\end{abstract}

\section{INTRODUCTION}

The genus Periclimenaeus Borradaile, 1915, includes a number of small pontoniine shrimps that occur mainly in all tropical waters, particularly on coral reefs, and live in association with a variety of sponge and ascidian hosts, generally as heterosexual pairs living in internal cavities of their hosts. They are characterised by the presence of grossly unequal chelae on the second pereiopods, the larger of which has a conspicuous molar process on the dactylus, which opposes into a fossa on the fixed finger, the combination forming an effective sound-producing mechanism remarkably convergent with that found in the pontoniine genus Coralliocaris Dana and some genera of the Alpheidae.

Periclimenaeus is the second most speciose genus in the subfamily Pontoniinae, after Periclimenes Costa, 1844. At present 48 species are known from the Indo-West Pacific region where they are found mainly as associates of marine sponges, although a number are also known from ascidian hosts. The hosts of several species are yet to be identified. From Australian waters 19 species have so far been reported by Davie (2002) and P. minutus Holthuis, 1952, reported by Berggren (1997), was not included, making a total of 20 species. The discovery of further species from ascidian hosts collected at Ashmore Reef, north western Australia now raises the Australian Periclimenaeus fauna to 22 species, most of which are associated with sponges.

Four species of the genus Periclimenaeus have been previously reported from Western Australia. Periclimenaeus hecate was reported from Cape Jaubert by Balss (1921, as ? Coralliocaris hecate, and later from Maret Island, Western Kimberley
(Berggren, 1997), followed by $P$. bidentatus Bruce, 1970 , and $P$. pachydentatus Bruce, 1969, from Hibernia Reef (Bruce 1992) and more recently, $P$. minutus, from Churchill and Albert Reefs, Western Kimberley (Berggren 1997). Periclimenaeus bidentatus and $P$. minutus are sponge associates, the others are associates of ascidians.

Further information is also provided on $P$. pachydentatus, with a record from the Philippines, the first occurrence outside Australian waters.

CL refers to the post-orbital carapace length; NTM, Northern Territory Museum, Darwin; WAM, Western Australian Museum, Perth; ZMUC, Zoology Museum, University of Copenhagen.

\section{SYSTEMATICS}

\section{Subphylum CRUSTACEA}

Order DECAPODA Latreille, 1802

Family PALAEMONIDAE Rafinesque, 1815

Subfamily PONTONIINAE Kingsley, 1878

Genus Periclimenaeus Borradaile, 1915

Periclimenaeus Borradaile, 1915: 207.

Periclimenaeus kottae sp. nov.

Figures 1-3

\section{Material Examined}

Australia, Western Australia: 1 ovig. 9, holotype, stn WAM 174.93, Ashmore Reef, outer slope, 6-16 m, coll. L. Marsh, 16 September 1986, WAM C 34444. 


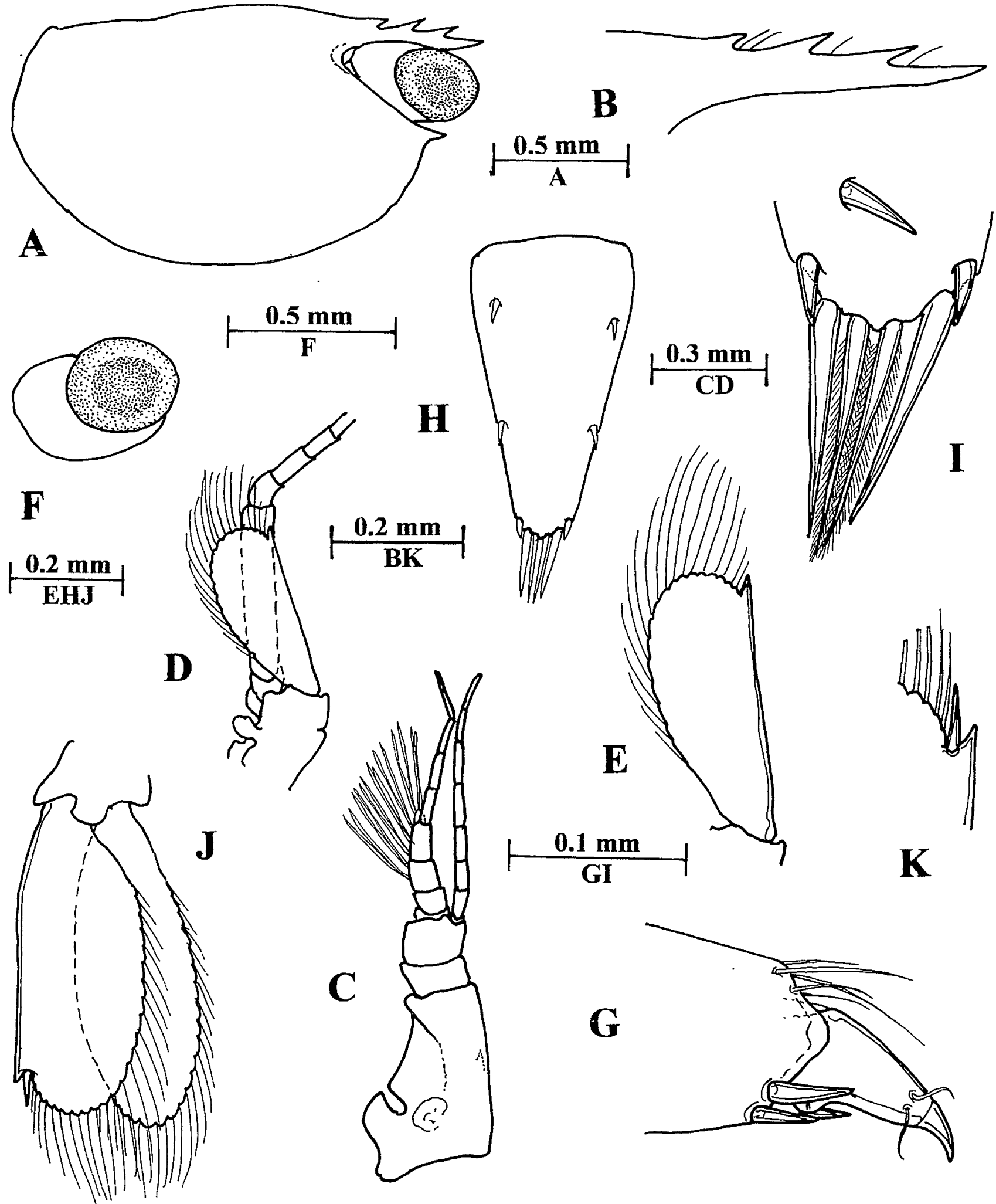

Figure 1 Periclimenaeus kottae sp. nov., holotype, ovigerous female. A, carapace and rostrum. B, rostrum. C, antennule. D, antenna. E, same, scaphocerite. F, eye. G, third pereiopod, distal propod and dactyl. H, telson. I, same posterior spines, dorsal spine inset. J, uropod. $\mathrm{K}$, same, posterolateral angle of exopod.

\section{Diagnosis}

Rostral dentition 3/0, without supraorbital spines, first pereiopod chela distally subspatulate, major second pereiopod with chela smooth, dactylar cutting edge distally finely denticulate, merus ventrally spinulate, minor second pereiopod dactyl cutting edge coarsely dentate, ambulatory dactyls completely unarmed, with rounded boss proximally, exopod of uropod laterally unarmed. 


\section{Description}

A very small pontoniine shrimp of subcylindrical body form.

Rostrum (Figure 1B). Short, about 0.45 of CL, to level of anteroverted corneal margin, not reaching to distal margin of proximal segment of antennular peduncle, slender, without distinct carinae, dorsal margin with small proximal tooth at about 0.25 of rostral length, with two larger acute teeth at about 0.5 and 0.75 , with sparse interdental setae, ventral margin unarmed.

Carapace (Figure 1A). Smooth, orbit feebly developed, inferior orbital angle obsolete, supraorbital spines or tubercles and hepatic spines absent, antennal spine acute, marginal, anterolateral margin of branchiostegite not produced, broadly rounded.

Abdomen. Smooth, first segment without anterodorsal lobe, pleura broadly rounded, sixth segment about 0.4 of CL, 1.4 times longer than deep, 1.2 times longer than fifth segment, posterolateral angle blunt, posteroventral angle well developed, acute.

Telson (Figure 1H). About 0.85 of CL, 1.9 times longer than anterior width, lateral margins sublinear, converging strongly posteriorly, with two pairs of small subequal dorsal spines, about 0.08 of telson length, at 0.24 and 0.62 of telson length, posterior margin (Figure 1I) rounded, without acute median point, about 0.35 of anterior width, with small lateral spines, slightly smaller than dorsal spines, well developed intermediate spines, about 0.25 of telson length, submedian spines subequal to dorsal spines in length, more slender and setulose.

Antennule (Figure 1C). Short, robust, proximal segment about 1.5 times longer than basal width, with small ventromedial tooth, lateral border concave, without distinct distolateral tooth, stylocerite short, broad, acute, reaching to about 0.3 of segment length; statocyst present; intermediate and distal segments short and stout, combined equal to about 0.5 of proximal segment length, upper flagellum short, biramous, proximal three segments stout, fused, shorter free ramus with single short segment, longer ramus with four subcylindrical segments, about seven groups of aesthetascs; lower flagellum of similar length, with seven subcylindrical segments.

Antenna (Figure 1D). Short, stout, coxal segment with conspicuous medial tubercle, basicerite laterally unarmed, carpocerite subcylindrical, about 6.0 times longer than width, extending to level of distal margin of antennular peduncle, flagellum short; scaphocerite (Figure 1E) small, about 2.6 times longer than distal width, not exceeding carpocerite, lateral margin straight, with small acute distolateral tooth reaching to level of distal margin of lamella.

Eye (Figure 1F). Cornea well pigmented, globular, without accessory pigment spot, diameter about 0.25 of $\mathrm{CL}$, stalk short, robust.

Mandible (Figure 2A). Rather weak, corpus without palp: molar process (Figure 2B) subcylindrical, tapering slightly distally, obliquely truncate, with two acute teeth posteriorly, margins setose: incisor process (Figure $2 \mathrm{C}$ ) slender, tapering distally, terminating in two small acute teeth.

Maxillula. Lost in dissection. Lower lacinia short, stout, with few long robust distal spines.

Maxilla (Figure 2D). Palp about 3.2 times longer than wide, without preterminal plumose seta, with sparse short plumose setae proximo-laterally; basal endite simple, distally expanded, with about 8 slender simple setae, coxal region convex, scaphognathite normal, about 2.25 times longer than broad.

First maxilliped (Figure 2E). Palp subcylindrical, with preterminal seta medially, basal endite sparsely setose distally, glabrous proximally, coxal endite not distinguishable, non-setose, caridean lobe broad, sparsely setose, with about 12 short plumose setae, flagellum slender with four terminal plumose setae; epipod small, deeply bilobed.

Second maxilliped (Figure 2F). Of normal form, dactylar segment about 2.5 times longer than broad, with numerous long coarsely serrulate spines, exopod slender with four plumose terminal setae, epipod small, simple, elongate, without podobranch.

Third maxilliped (Figure 2G). Short, stout, reaching to about half length of proximal segment of antennular peduncle, ischiomerus fully fused to basis, combined segment about 3.3 times longer than broad centrally, medial margin sparsely setose, basal region strongly convex, penultimate segment about 0.8 of combined segment length, 2.5 times longer than width, sparse slender spines medially, distal segment 2.5 times longer than proximal width, tapering distally with few groups of slender spines; exopod normal, with four plumose terminal setae; coxa without medial process, lateral plate suboval, elongate, without arthrobranch.

Thoracic sternites. Narrow, without special features.

First pereiopod (Figure 2A). Short, robust, exceeding carpocerite by about half propod length; chela (Figure 2B) with compressed palm, about 1.4 times longer than deep, fingers subequal to palm length, slightly subspatulate, sparsely setose, cutting edges sharp distally, entire, medially and laterally, tips bidentate: carpus short, stout, 2.5 times longer than wide, tapering proximally, about 0.7 of palm length; merus subcylindrical, 3.4 times longer than width, 1.2 times carpal length, slightly shorter than chela; proximal segments without special features.

Major second pereiopod (Figure 2C). Well developed, chela about 2.0 times $C L$, palm smooth, 

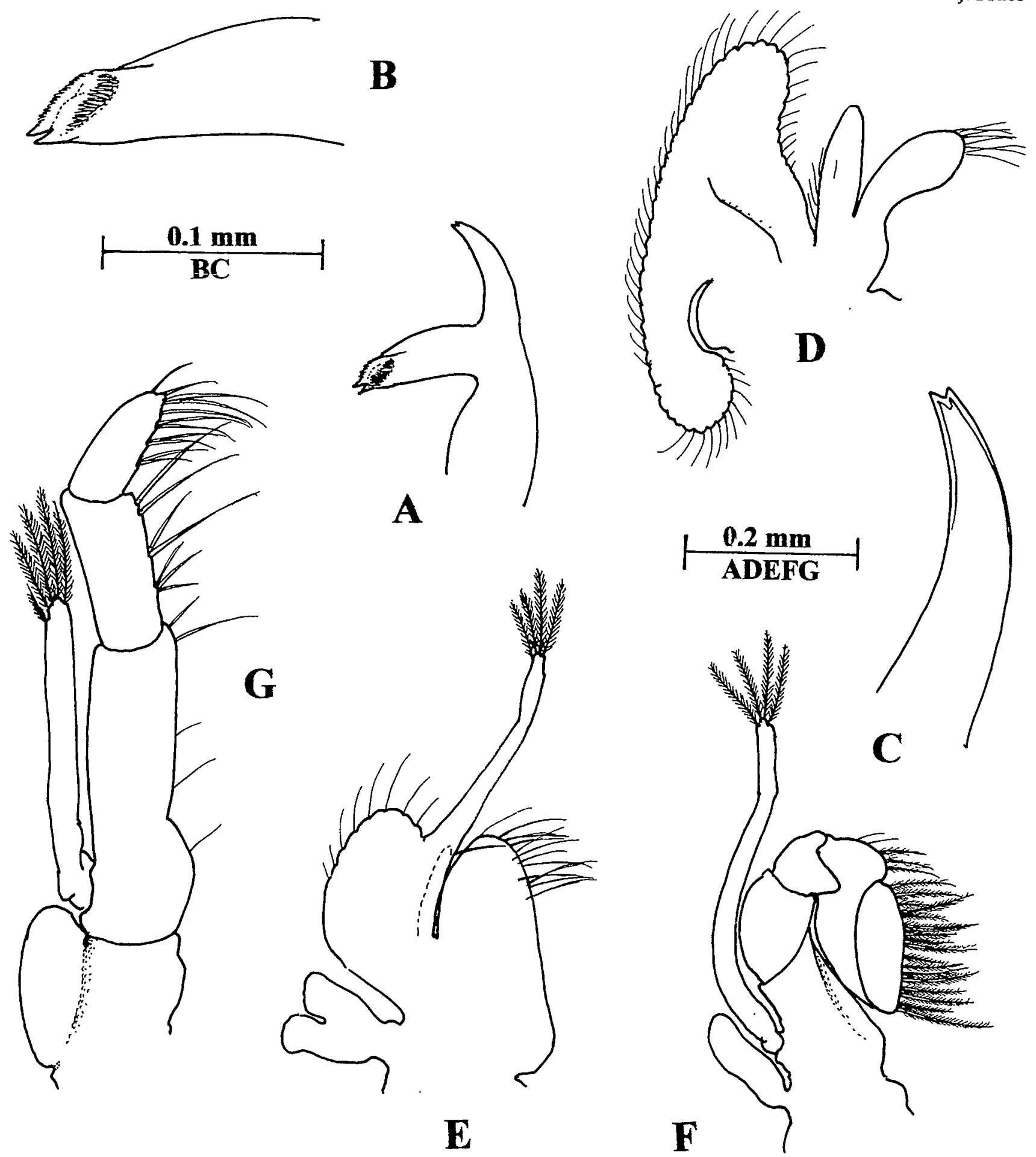

B
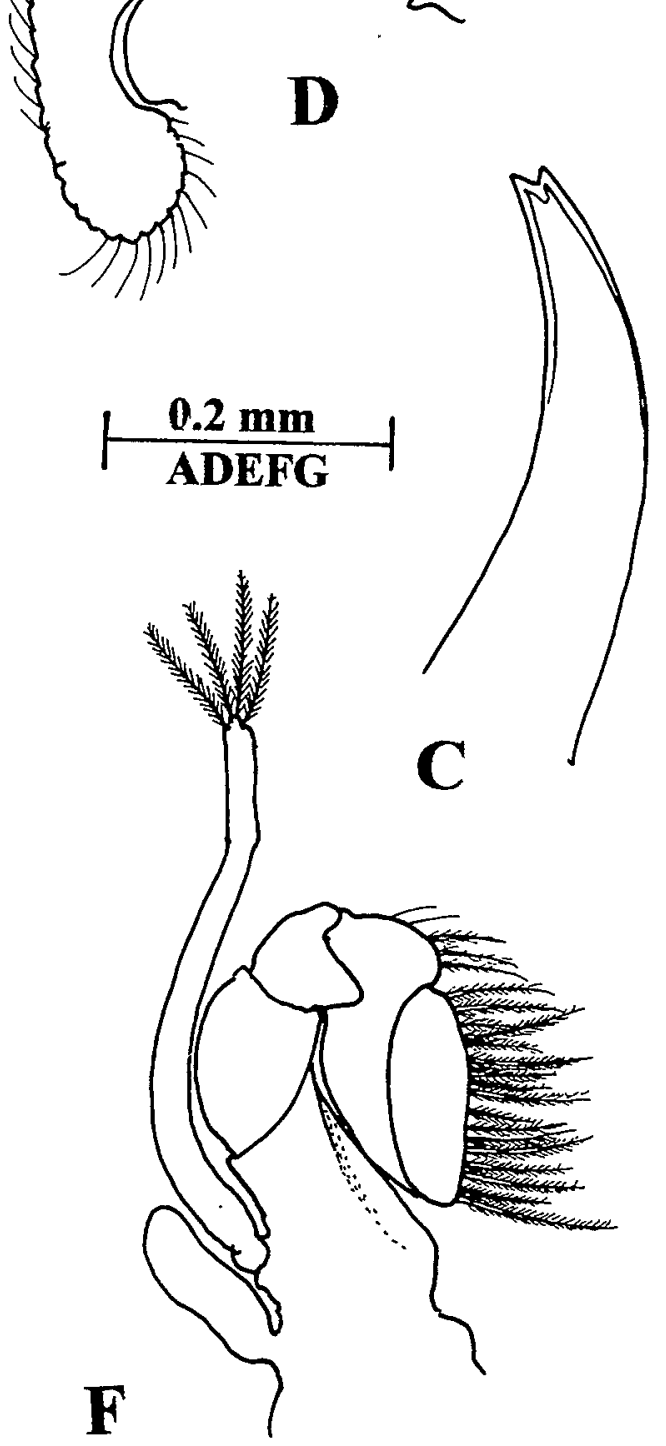

Figure 2 Periclimenaeus kottae sp. nov., holotype, ovigerous female. A, mandible. B, same, molar process. C, same, incisor process. D, maxillula. E, first maxilliped. $F$, second maxilliped. $G$, third maxilliped.

glabrous, 1.7 times longer than deep, moderately compressed, tapering slightly distally, fingers (Figure 2D) about 0.37 of palm length, dactylus about 1.5 times longer than deep, outer margin semicircular, cutting edge with large low molar process proximally, anterior margin slightly bilobed, distal cutting edge (Figure 2E) short, concave, finely denticulate with blunt imbricate denticles, tip stout, acute, fixed finger with large deep fossa proximally, cutting edge distally straight, entire, tip acute, strongly hooked; carpus about 0.38 of palm length, broadly expanded distally and tapered proximally, about as long as wide distally, unarmed; merus (Figure $2 \mathrm{~F}$ ) about 0.3 of palm length, 1.5 times longer than deep, tapering slightly distally, with 4 small acute ventral denticles; ischium slightly longer than merus, robust, tapering proximally, 2.0 times longer than central width, unarmed; basis and coxa robust, without special features. 

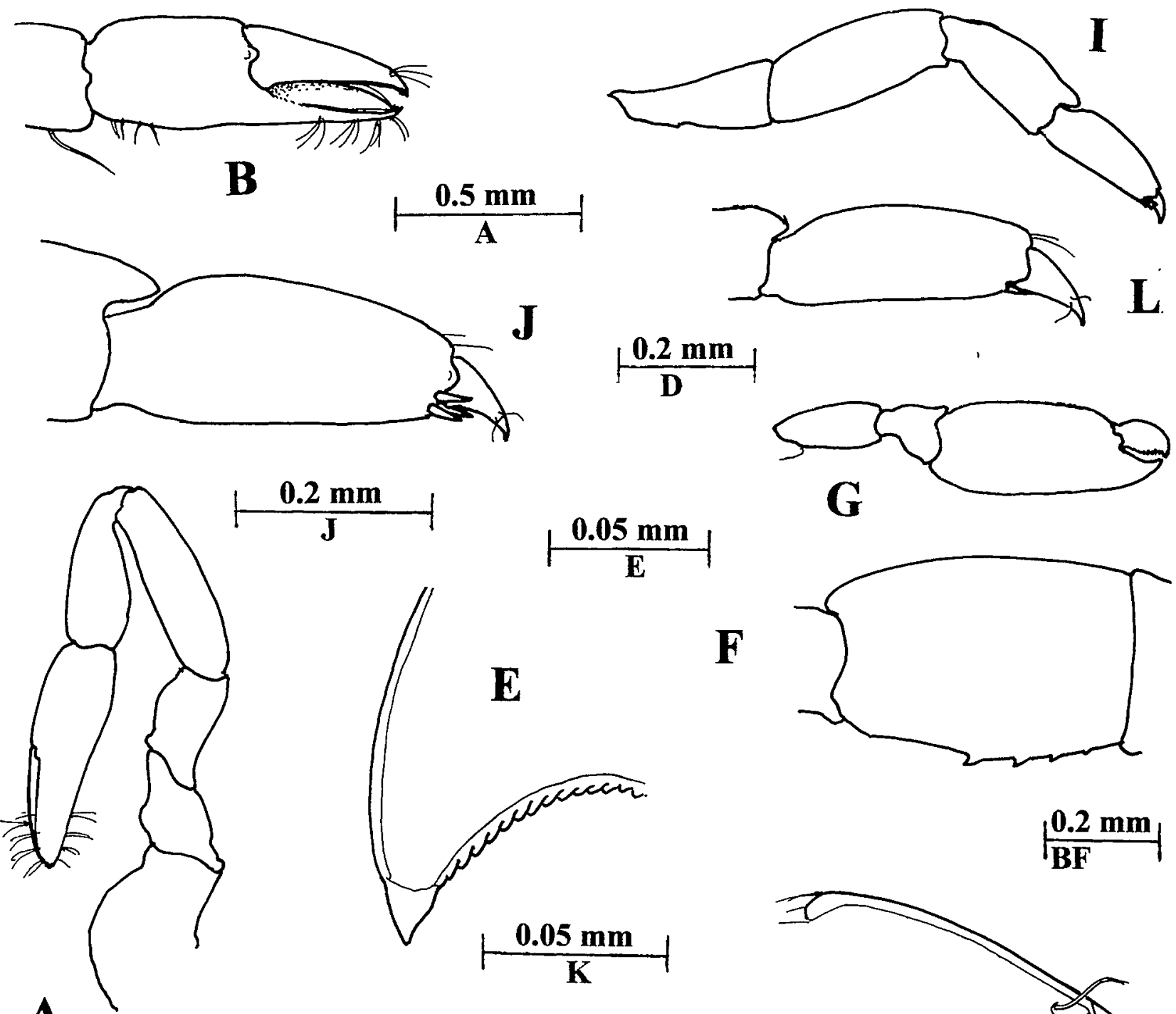

F

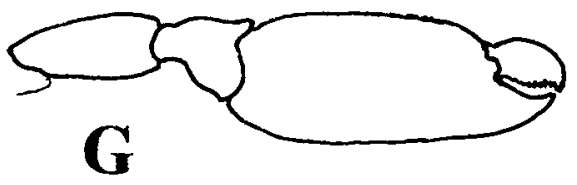

A
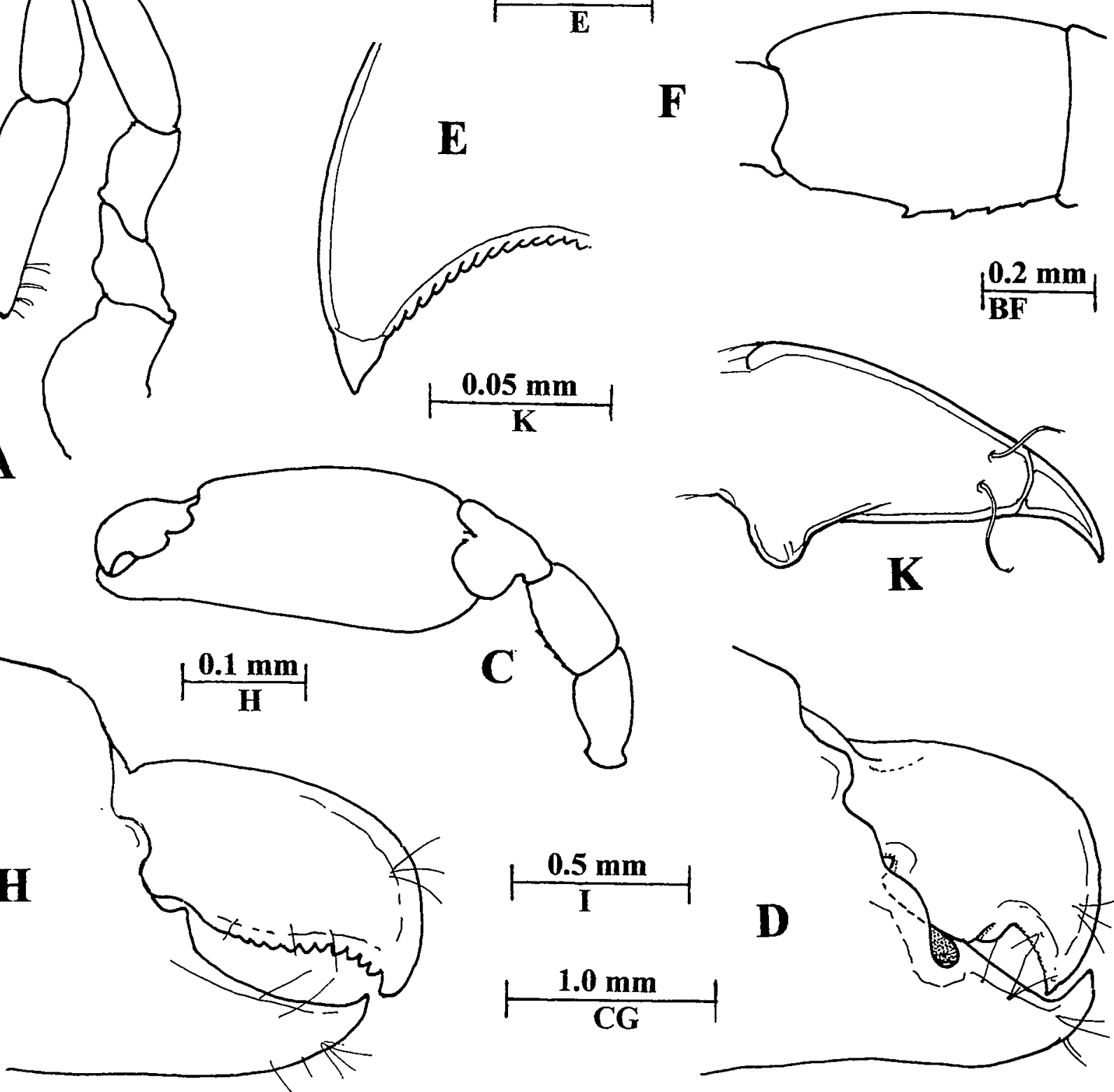

$\frac{0.2 \mathrm{~mm}}{\mathrm{BF}}$

$\frac{0.2 \mathrm{~mm}}{\mathrm{D}}$

Figure 3 Periclimenaeus kottae sp. nov., holotype, ovigerous female. A, first pereiopod. B, same, chela. C, major second pereiopod. D, same, fingers. E, same, cutting edge of dactylus. F, same, merus. G, minor second pereiopod. $\mathrm{H}$, same, fingers. I, third pereiopod. J, same, propod and dactyl. $\mathrm{K}$, same, dactyl. L, fourth pereiopod, propod and dactyl. 
Minor second pereiopod (Figure 3G). Smaller than major pereiopod; chela about 0.8 of major chela palm length, 1.2 of $C L$, palm 2.0 times longer than deep, subuniform, slightly compressed, smooth, glabrous, fingers (Figure $3 \mathrm{H}$ ) about 0.27 of palm length, dactylus over-reaching fixed finger, about 2.0 times longer than central depth, outer margin strongly convex, cutting edge sinuous with about 12 coarse, blunt teeth of increasing size distally, tip bluntly hooked; fixed finger about 1.2 times longer than proximal depth, cutting edge not grooved, concave, entire, with small acute tooth proximally, tip curved, acute; carpus about 0.38 of palm length, 1.2 times longer than distal width, tapered proximally, expanded distally, unarmed; merus about 0.6 of palm length, 2.5 times longer than greatest depth, tapering slightly proximally, without ventral denticulations; ischium about 0.8 of meral length, 2.8 times longer than distal width, tapering proximally, unarmed; basis and coxa without special features.

Third pereiopod (Figure 3I). Short, robust, exceeding antennular peduncle by chela length, dactyl (Figure 1G) about 0.27 of propod length, corpus (Figure $3 \mathrm{~K}$ ) compressed, twice as long as central depth, tapering distally, distal width about 0.5 of proximal width, dorsal margin feebly convex, ventral margin without distal accessory tooth, distally almost straight, proximally with large rounded boss, with pair of distolateral sensory setae, unguis stout, simple, curved, about 1.75 times longer than basal width, 0.33 of corpus length; propod (Figure 3J) about 0.3 of CL, stout, 2.5 times longer than maximal depth at about 0.33 of length, with stout similar distomedial, distoventral and distolateral spines, about 0.12 of propod length; carpus stout, 1.5 times broader than propod, 2.4 times longer than wide, unarmed; merus 1.5 times propod length, 2.5 times longer than width, unarmed; ischium subequal to carpus length, 2.5 times longer than distal width, tapering proximally, unarmed; basis and coxa robust, without special features. Fourth pereiopod similar. Fifth pereiopod dactyl without ventral boss, 0.5 of propod length, propod 2.8 times longer than deep.

Uropod (Figure 1J). Protopodite unarmed; exopod 2.6 times longer than broad, lateral margin mainly straight, unarmed, with well developed acute distal tooth (Figure $1 \mathrm{~K}$ ), with mobile spine medially, reaching almost to level of distal margin of lamella; endopod subequal to exopod length, 2.6 times longer than wide.

Ova. Few, about 10, of normal size.

\section{Measurements (mm)}

Post-orbital carapace length, 0.9 ; carapace and rostrum, 1.4; total body length (approx.), 4.7; major second pereiopod chela, 1.85; minor second pereiopod chela, 1.15; length of ovum, 0.4 .

\section{Systematic Position}

Periclimenaeus kottae sp. nov. is most closely related to $P$. hecate (Nobili, 1904) and $P$. crassipes (Calman, 1939). It may be distinguished from the former species by its much smaller size, CL $0.9 \mathrm{~mm}$, and rostral dentition $3 / 0$ as opposed to $3.5 \mathrm{~mm}$ and $4-5 / 0$, in $P$. hecate. Also, rostrum more slender, not reaching distal margin of proximal segment of antennular peduncle vs distinctly exceeding distal margin of proximal segment; first pereiopod with carpus and merus shorter than chela os much longer; major second pereiopod with distal cutting edge of dactylus minutely denticulate, merus ventrally spinulate, vs entire and non-spinulate; minor second pereiopod chela with palm twice as long as deep, with dactylar cutting edge sinuous with about 12 coarse teeth $v$ s three times, and straight with about 40 finely acute teeth; ambulatory dactyl with corpus twice as long as basal width, with pronounced rounded ventral swelling proximally os subcircular, without proximal ventral swelling. From $P$. crassipes, $P$. kottae may again be distinguished by its much smaller size, total length $4.7 \mathrm{~mm}$ and rostral dentition $3 / 0$, vs $10.5 \mathrm{~mm}$ and $4 / 0$. Periclimenaeus crassipes has only been illustrated with a whole animal figure, and the dactyl of the fifth pereiopod provided by Calman (1939) and the third pereiopod, figured by Bruce (1974). The latter shows the "massive and flattened" appendage described by Calman, with the propod 2.7 times longer than proximal width and tapering very strongly distally, where its width is about 0.25 of the proximal width, quite unlike $P$. kottae. The carpus is even more inflated, length about 0.9 of the propod length, and almost twice as long as wide. The dactyl is, as remarked by Calman, without a basal protuberance, unlike $P$. kottae.

\section{Colouration \\ No data.}

\section{Host}

Didemnum membranaceum Sluiter, 1909. The host is a commonly occurring species from the tropical western Pacific, in Australia down to Houtman's Abrolhos on the west coast and Caloundra on the east; and it has also been recorded from Hong Kong.

\section{Etymology}

The species is dedicated to Dr Patricia Kott, A.O., in recognition of her contribution to the study of the Ascidiacea.

\section{Remarks}

Periclimenaeus kottae must be one of the smallest pontoniine shrimps recorded, with an adult total length of only $4.7 \mathrm{~mm}$. 
The vast majority of Periclimenaeus species have a biunguiculate dactyl on the ambulatory pereiopods, often with additional ornamentation. In the Indo West-Pacific region, only four species are known that lack biunguiculate dactyls on these appendages Most of these are rare and two are known from the type material only. These species do not appear to be closely related or to constitute a distinct group and the loss of the distal accessory tooth on the ambulatory dactyl has possibly occurred independently in several different evolutionary lines.

Periclimenaeus arthrodactylus Holthuis, 1952, is still known only from the holotype specimen collected from Pulau Sailus ketjil, Kepulauan Tenga, Indonesia, in 1899, from $18 \mathrm{~m}$ or less, from an unknown host. Periclimenaeus hecate (Nobili, 1904) was first reported from Djibouti and has been subsequently reported from Kenya, Comoro Islands, Seychelle Islands, Réunion, Maldive Islands, Indonesia, China and Western Australia in Diplosoma molle (Herdman, 1886). Periclimenaeus crassipes has been reported from off Oman and from Darwin Harbour, Northern Territory, in association with the ascidian Didemnum psammatoides. Periclimenaeus serrula Bruce and Coombes, 1995, is known only from the type material from Orontes Reef, Port Essington, Northern Territory, from 12 $\mathrm{m}$., from Leptoclinides incertus Sluiter. It may be noted that these species are found in association with three different ascidian host genera.

It may also be noted that the mouthparts of $P$. kottae closely resemble those of $P$. robustus. Borradaile, 1915, as illustrated in Borradaile (1917, plate 55 figures $20 \mathrm{f}-\mathrm{i}$ ), the type species of the genus Periclimenaeus. The mandible and maxillula of $P$. robustus were not illustrated.

These species do not appear to be closely related or to constitute a distinct group and the loss of the distal accessory tooth on the ambulatory dactyl has probably occurred independently in several different evolutionary lines.

These species may be conveniently distinguished from P. kottae by the following key.

\section{Key to Indo-West Pacific Periclimenaeus species with ambulatory dactyls lacking a distal accessory tooth}

1. Supraorbital spines present, third pereiopod dactyl large and slender, with articulated unguis, with minute ventral denticulations; R. 5/0 P. arthrodactylus Holthuis

- Supraorbital spines absent, third ambulatory dactyl with simple, non-articulated tip ......... 2

2. Dactyl of minor second pereiopod with cutting edge entire, of major second pereiopod minutely denticulate; $\mathrm{R} 4 / 0$.

P. serrula Bruce and Coombes
- Dactyl of minor second pereiopod with cutting edge dentate ... 3

3. Dactyl of minor second pereiopod with cutting edge with numerous small teeth, about 40 , along whole cutting edge; R. 4-5/0

P. hecate (Nobili)

- Dactyl of minor second pereiopod with cutting edge with few large teeth (about 10-12) ....... 4

4. Large species, dactyl of minor second pereiopod much longer than fixed finger, with about 10 blunt teeth distally; carpus and propod of third pereiopod greatly swollen, propod 3 times broader proximally than distally; dactylus without basal process; R. 4/0 P. crassipes (Calman)

- Small species, dactyl of minor second pereiopod slightly longer than fixed finger, with about 12 blunt teeth distally; carpus and propod of third pereiopod not greatly swollen, propod less than twice broader proximally than distally; dactylus with rounded basal process; R. 3/0

P. kottae sp. nov.

\section{Periclimenaeus matherae sp. nov. Figures 4-8}

\section{Material Examined}

Australia, Western Australia: $1 \delta$, holotype, Ashmore Reef, West Lagoon entrance. $12^{\circ} 013.26^{\prime} \mathrm{S}$ $122^{\circ} 059.28^{\prime} \mathrm{E}, 4-7 \mathrm{~m}$, coll. K. Gowlett-Holmes, 1 October 2002, AJB \#3225, NTM Cr013631.

\section{Diagnosis}

Rostrum well developed, slender, dentition 7/0; supraorbital tubercles present; inferior orbital angle produced; antennal spine large; first abdominal segment without anterodorsal lobe; first pereiopod slender, chela fingers subspatulate, cutting edges entire; major second pereiopod massive, dactyl with large molar process, cutting edge distally entire, palm finely asperulate, merus ventrally entire; minor second pereiopod dactyl elongate, exceeding fixed finger, cutting edge concave, finely denticulate, fixed finger grooved, inner cutting minutely denticulate; third pereiopod dactylus biunguiculate, ventral border minutely denticulate, without acute basal process, propod with 3 distal spines, 5 ventral spines; uropodal exopod laterally unarmed; telson with large dorsal spines at 0.2 and 0.6 of telson length.

\section{Description}

A medium sized species of Periclimenaeus, of subcylindrical body form.

Rostrum (Figure 4B). Slender, compressed, acute, 


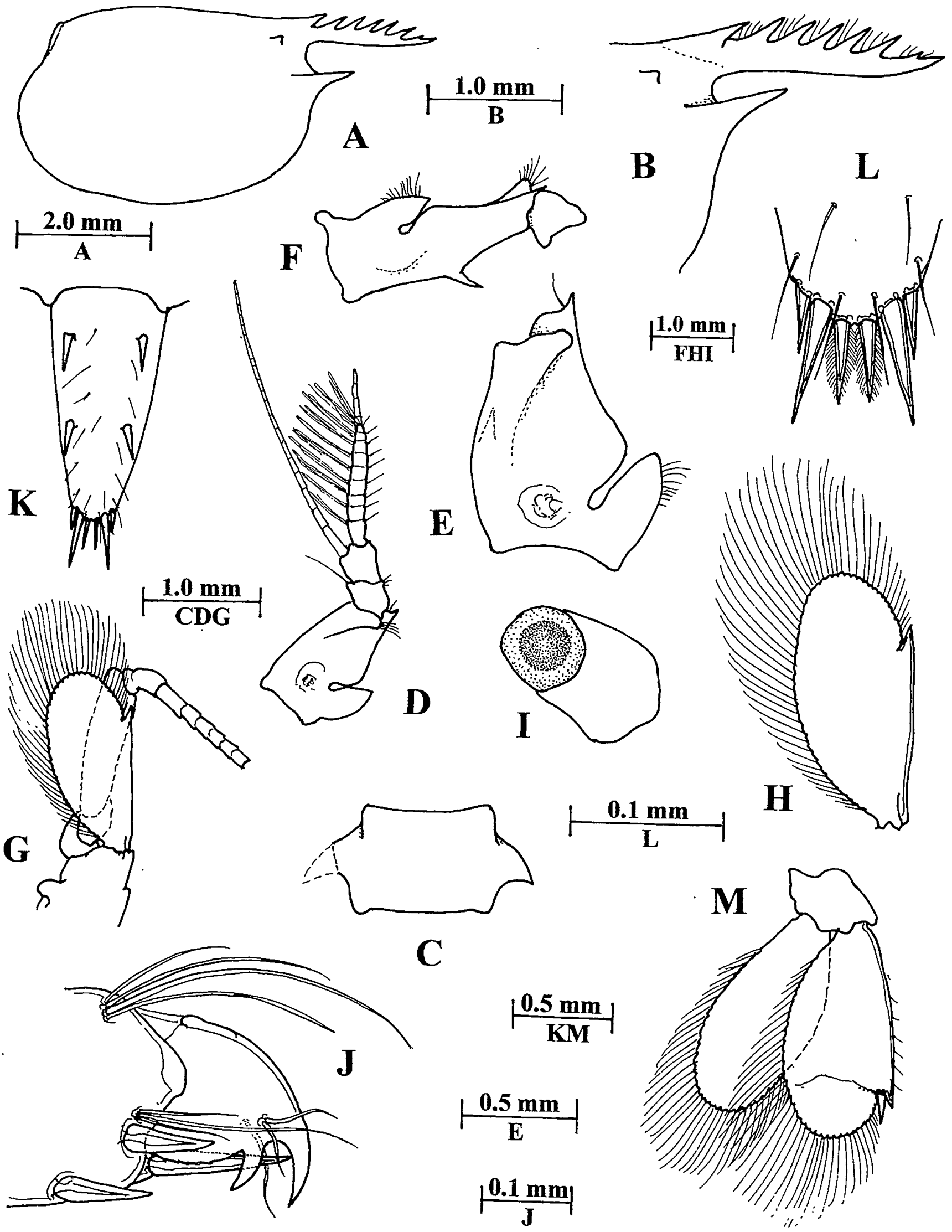

Figure 4 Periclimenaeus matherae sp. nov., holotype male. A, carapace and rostrum. B, same, rostrum and orbital region. $C$, sixth abdominal segment, dorsal. $D$, antennule. $E$, same, proximal segment, dorsal. $F$, same, lateral. $\mathrm{G}$, antenna. $\mathrm{H}$, same, scaphocerite. I, eye, dorsal. J, third pereiopod, distal propod and dactyl. $\mathrm{K}$, telson. $\mathrm{L}$, same, posterior spines. $\mathrm{M}$, uropod. 
reaching to about to middle of distal segment of antennular peduncle, about 0.5 of $\mathrm{CL}$, dorsal margin sublinear, with 7 acute teeth, first tooth situated over posterior orbital margin, slightly transversely broadened, distal tooth small, intervening teeth long, slender, acute, with short plumose setae on dorsal edges, teeth longer than rostral depth, ventral border mainly straight, slightly up-curved distally, unarmed, non-setose.

Carapace (Figure 4A). Smooth, glabrous, with small subacute supraorbital tubercles, antennal spine large robust, inferior orbital angle (Figure 7A) produced as small blunt process, hepatic spine absent, anterolateral branchiostegite not produced, broadly rounded.

Abdomen. Smooth, glabrous; first segment without anterodorsal lobe, pleura broadly rounded, sixth segment (Figure 4C) about 0.3 of CL, 2.8 times longer than deep, 1.2 times longer than fifth segment, posterolateral angle blunt, posteroventral angle well developed, acute.

Telson (Figure 4K). About 0.6 of CL; dorsal surface sparsely setose; 2.0 times longer than anterior width, lateral margins feebly concave, posteriorly convergent, with 2 pairs of submarginal dorsal spines (Figure 8G), at about 0.2 and 0.6 of telson length, spines about 0.15 of telson length, posterior spines slightly more slender than anterior, posterior margin (Figure 4L) about 0.4 of anterior margin width, lateral spines small, acute, about 0.75 of dorsal spine length, intermediate spines robust, about 5.5 times longer than basal width, 0.25 of telson length, 1.8 times lateral spine length, submedian spines 0.75 of intermediate spine length, setulose.

Antennule (Figure 4D). Short, robust, proximal segment (Figure 4E) with medial length about 1.6 times longer than basal width, with large slender acute ventromedial tooth (Figure $4 \mathrm{~F}, 8 \mathrm{~F}$ inset), lateral border angular, distally concave, with well developed distolateral lobe (Figure $8 \mathrm{~F}$ ) with acute distolateral tooth, stylocerite short, broad, subacute, reaching to about 0.4 of segment length, distolateral margin setose; statocyst present, granular statolith; intermediate and distal segments short and stout, combined equal to about 0.6 of proximal segment length, upper flagellum short, biramous, proximal 7 segments stout, fused, shorter free ramus with single short segment, longer ramus with 4 subcylindrical segments, about 16 groups of aesthetascs medially, with short simple spiniform setae laterally; lower flagellum of similar length, with about 20 subcylindrical segments.

Antenna (Figure 4G). Short, stout; coxal segment with conspicuous medial tubercle, basicerite laterally unarmed, carpocerite subcylindrical, about 4.0 times longer than distal width, extending to slightly beyond distal margin of scaphocerite, flagellum short; scaphocerite (Figure $4 \mathrm{H}$ ) small, about 2.2 times longer than distal width, not exceeding carpocerite, lateral margin straight, with well developed acute distolateral tooth at about 0.68 of lamellar length.

Eye (Figure 4I). Cornea hemispherical, well pigmented, diameter about 0.16 of $\mathrm{CL}$, without accessory pigment spot; stalk subcylindrical, 1.2 times corneal diameter proximally, tapering distally, about 1.2 times longer than basal width.

Mandible (Figure 5A). Corpus normal, without palp; molar process (Figure 8A,B) subcylindrical, tapering slightly, transversely oblique distally, with single acute ventral tooth, margins fringed with dense long slender setae; incisor process (Figure 8C) slender, curved, transversely truncate distally with five small subequal acute teeth.

Maxillula (Figure 5B). Palp (Figure 8D) slender, feebly bilobed distally, lower lobe with small tubercle bearing single short simple seta; upper lacinia (Figure 8E) short, broad, distal margin transversely truncate, with 11 slender acute simple teeth, fully fused to lacinia, with sparse simple setae; lower lacinia short, blunt, with numerous distal setae.

Maxilla (Figure 5C). Palp elongate, slender, nonsetose; basal endite bilobed, upper lobe short, broader than lower, with 9 simple setae distally; lower lobe damaged; coxal endite obsolete, medial margin convex, non-setose; scaphognathite well developed, 2.5 times longer than broad, anterior lobe broad, 1.2 times longer than wide.

First maxilliped (Figure 5D). Of normal form; palp slender, elongate, flattened, extending well beyond distal margin of basal endite, with single short simple seta at 0.66 of medial margin length; basal endite basal endite sparsely setose distally, glabrous proximally, coxal endite not distinguishable, sparsely setose, exopod with caridean lobe broad, 2.5 times longer than wide, with numerous plumose marginal setae; flagellum slender, with 7 plumose terminal setae; epipod small, deeply bilobed, distal lobe larger than proximal.

Second maxilliped (Figure 5E). Of normal form; dactylar segment narrow, 4.0 times longer than wide, with numerous finely serrulate spines medially; propodal segment well developed, distomedial border convex, with numerous finely serrulate spines; carpus, ischiomerus and basis without special features; exopod with well developed flagellum, with 7 plumose distal setae; coxa angularly produced medially, with few simple setae, epipod small, suboval, without podobranch.

Third maxilliped (Figure 5F). Of normal form, reaching to about distal end of carpocerite; endopod with ischiomerus semi-fused to basis, combined segment about 4.4 times longer than central width, medial border sparsely setose, with simple setae, coxal border convex, penultimate segment subcylindrical, about 4.0 times longer 


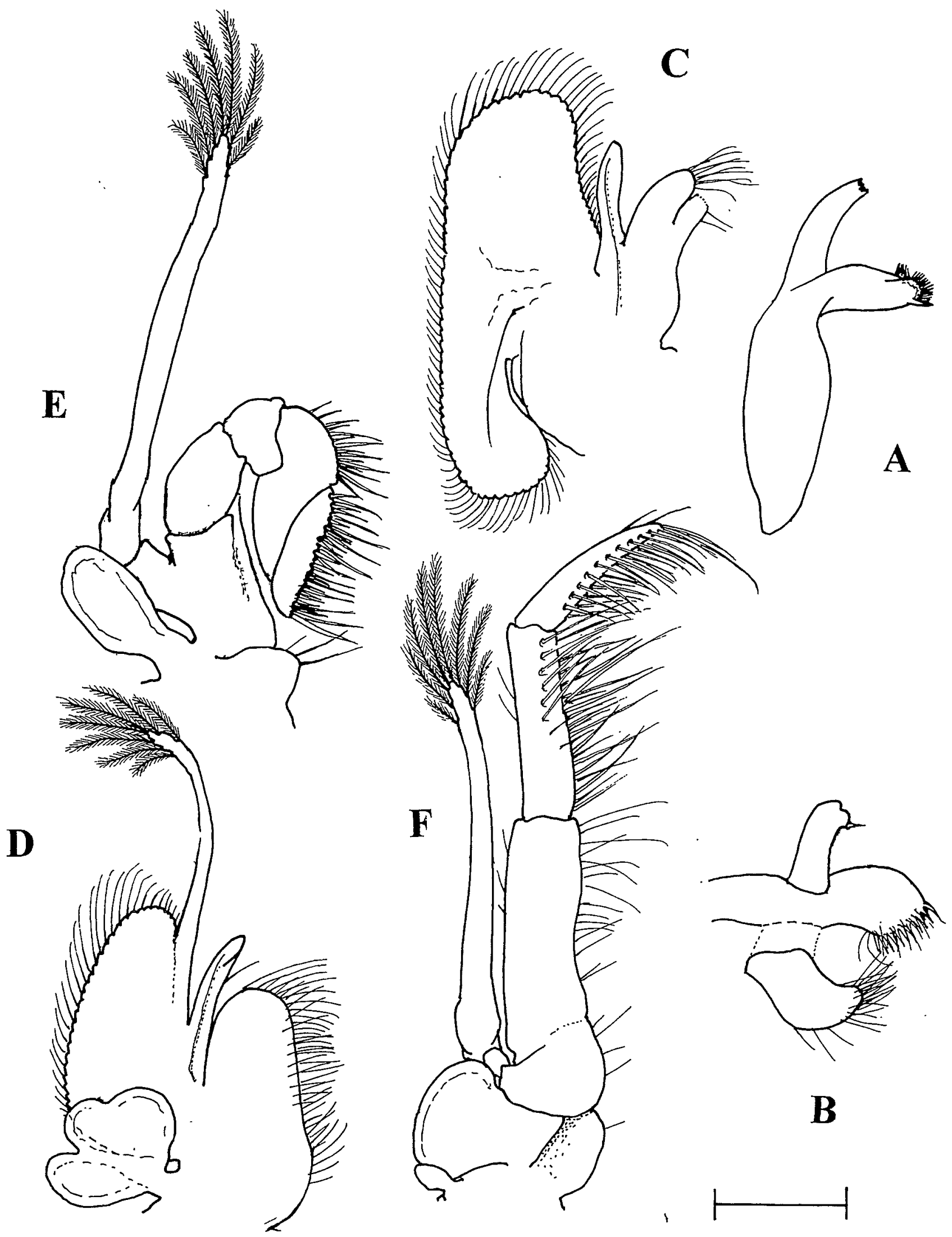

Figure 5 Periclimenaeus matherae sp. nov., holotype male. A, mandible. B, maxillula. C, maxilla. D, first maxilliped. E, second maxilliped. F, third maxilliped. Scale bar $0.5 \mathrm{~mm}$. 

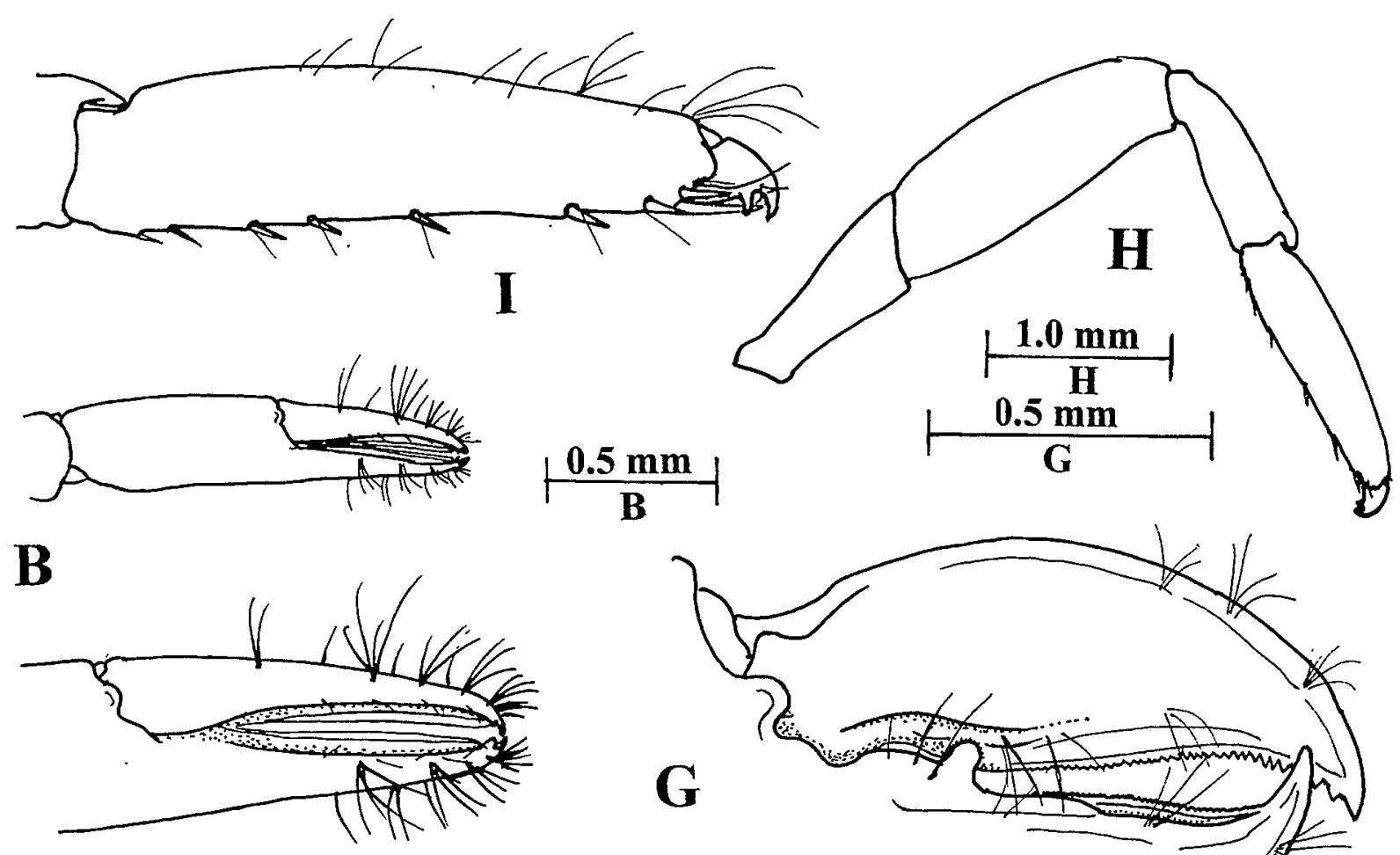

C
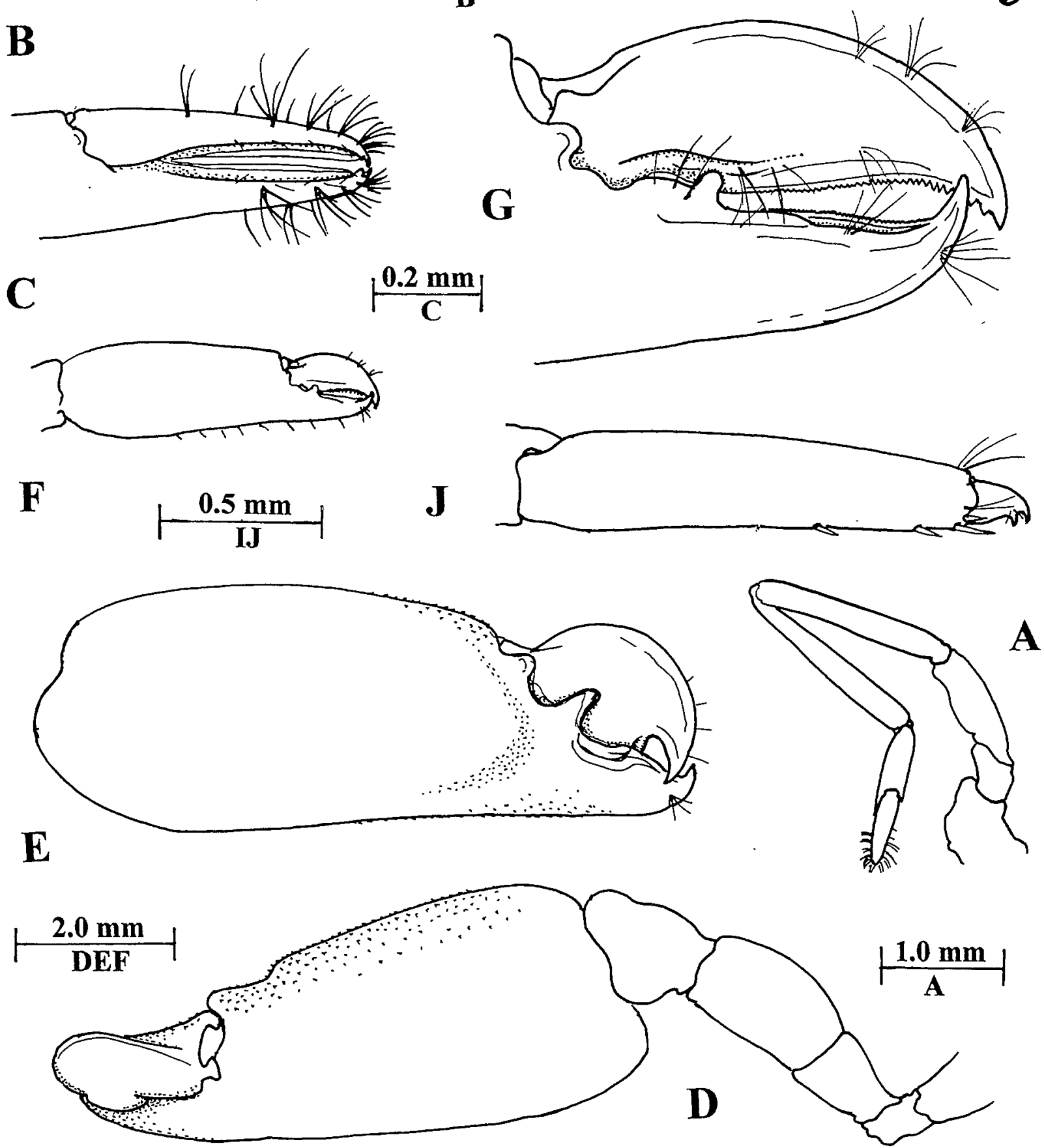

Figure 6 Periclimenaeus matherae sp. nov., holotype male. A, first pereiopod. B, same, chela. C, same, fingers. D, major second pereiopod. E, same, chela. F, minor second pereiopod, chela. G, same, fingers. H, third pereiopod. I, same, propod and dactyl. J, fourth pereiopod, propod and dactyl. 


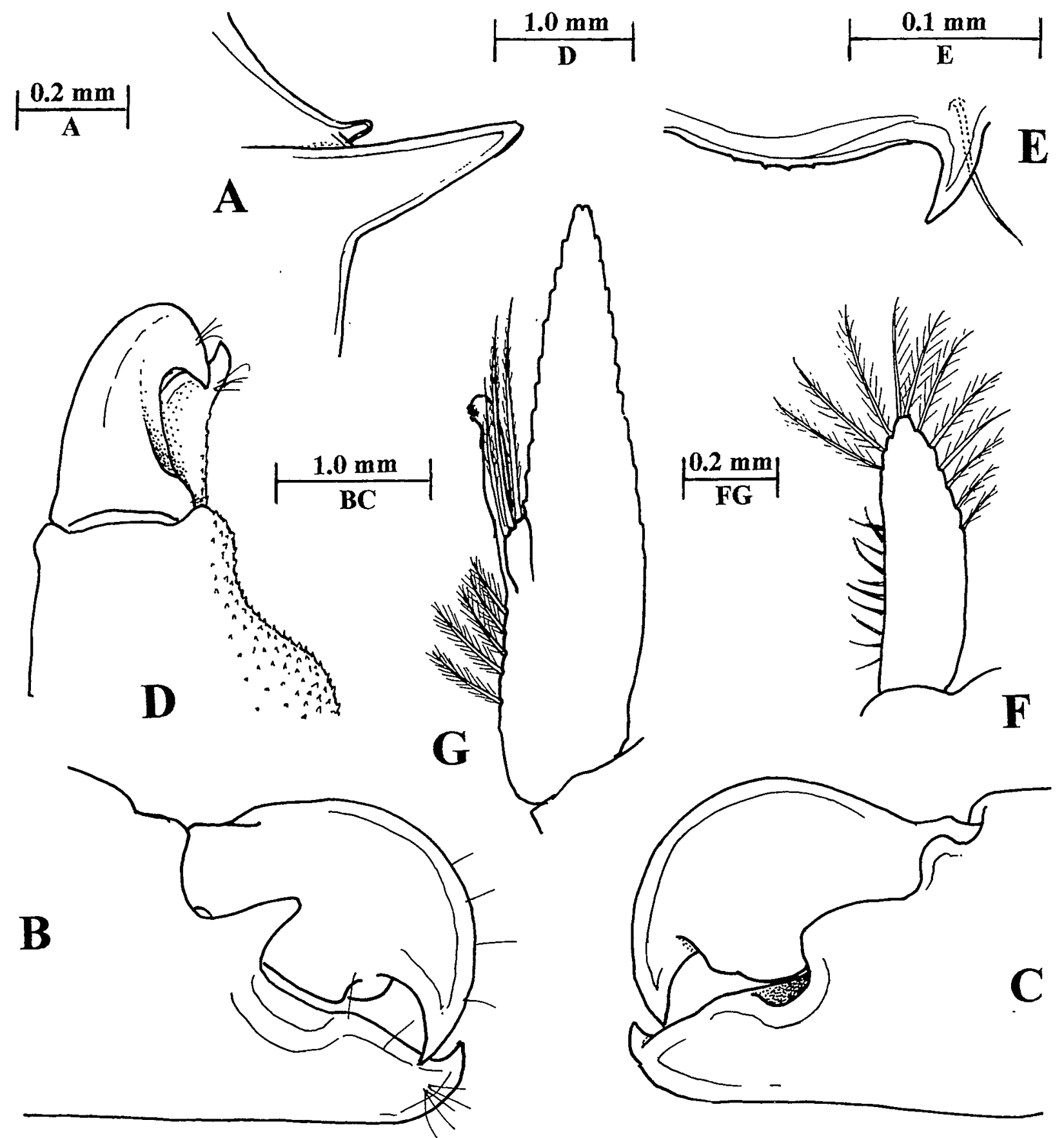

Figure 7 Periclimenaeus matherae sp. nov., holotype male. A, antennal spine and inferior orbital angle, lateral. B, major second pereiopod, fingers, medial aspect. C, same, lateral aspect. D, same, dorsal aspect. E, third pereiopod dactyl, ventral margin of corpus. F, first pleopod, endopod. G, second pleopod, endopod and appendices.

than central width, scarcely tapering distally, about 0.66 of antepenultimate segment length, with double rows of spiniform setae medially, terminal segment about 0.9 of penultimate segment length, 4.5 times longer than basal width, tapering distally, with double rows of spiniform setae medially; exopod flagellum as in second maxilliped, with 8 distal setae; coxa with oval lateral plate, medial margin convex, not produced, rudimentary arthrobranch present.

Thoracic sternites. Narrow, without discernable armament.
First pereiopod (Figure 6A). Slender, exceeding antennular peduncle by about 0.4 of meral length; chela (Figure 6B) slender, palm subcylindrical, slightly compressed, about 2.5 times longer than depth, sparsely setose, fingers (Figure 6C) 0.8 of palm length, slender, tapering, with numerous tufts of short setae, feebly spatulate, lateral margins entire, tips feebly bidentate; carpus about 1.5 times chela length, subcylindrical, 8.0 times longer than distal width, tapering proximally, unarmed; merus subequal to carpal length, subcylindrical, 7.5 times longer than maximal width, unarmed; ischium. 
subequal to chela length; basis and coxa without special features.

Major second pereiopod (Figure 6D). Second pereiopods well developed, grossly unequal and dissimilar. Major chela (Figure 6E) about 2.0 times $\mathrm{CL}$, palm inflated, oval in section, 2.0 times longer than central depth, tapering distally, glabrous, densely covered with minute asperities except on ventral aspect, fingers (Figure $7 B, C, D$ ) about 0.32 of palm length, dactylus robust proximally, compressed distally, about 1.8 times longer than deep, lateral margin hemispherical, stout, smooth, cutting edge with large molar process proximally, distal margin feebly bilobed, about 0.25 of dactyl length, concave, sharp, entire, tip very acute; fixed finger about 0.8 of dactylus length, 1.3 times longer than proximal depth, cutting edge with deep fossa on proximal half, dorsal margin with large subacute process, ventral margin with broad lobe, distal half entire, blunt, unarmed, tip strongly curved, acute; carpus about 0.27 of palm length, robust, about 2.0 times broader than proximal width, distally expanded, unarmed; merus robust, 0.33 of palm length, 1.6 times longer than central width, slightly swollen centrally, unarmed; ischium about 0.92 of meral length, 1.2 times longer than distal width, tapering proximally, basis and coxa slender, without special features.

Minor second pereiopod. Much smaller than major pereiopod. Chela (Figure 6F) about 0.85 of CL, 0.44 of major chela length, palm subcylindrical, slightly compressed, tapering slightly distally, about 2.4 times longer than maximal width, smooth, glabrous, dactylus (Figure 6G) about 0.4 of palm length, compressed, about 2.8 times longer than central depth, extending well beyond end of fixed finger, dorsal margin convex, sparsely setose, cutting edge sinuous, finely denticulate with about 45 small acute teeth throughout length, size increasing distally, minute proximally, tip acute, small, feebly hooked; fixed finger (Figure 6G) about 2.2 times longer than basal width, cutting edge deeply grooved proximally, medial and lateral margins each with blunt processes, ventral process larger than dorsal, both minutely denticulate distally, dorsal margin obsolete distally, ventral margin minutely denticulate over most of length, tip stout, acute, strongly hooked; proximal segments similar to major second pereiopod but smaller.

Third pereiopod (Figure 6H). Robust, exceeding antennular peduncle by propod and dactyl; dactyl (Figure 4J) with corpus short, about 0.14 of propod length, strongly compressed, dorsal length about 0.95 of basal width, tapering strongly distally, almost subcircular, dorsal margin convex, ventral margin (Figure 7E) with strong acute recurved accessory tooth distally, convex proximally, with four minute denticulations, without acute proximal tooth, unguis clearly demarkated, about 2.0 times longer than basal width, 0.56 of dorsal corpus margin length; propod (Figure $6 \mathrm{I}$ ) about 0.38 of CL,
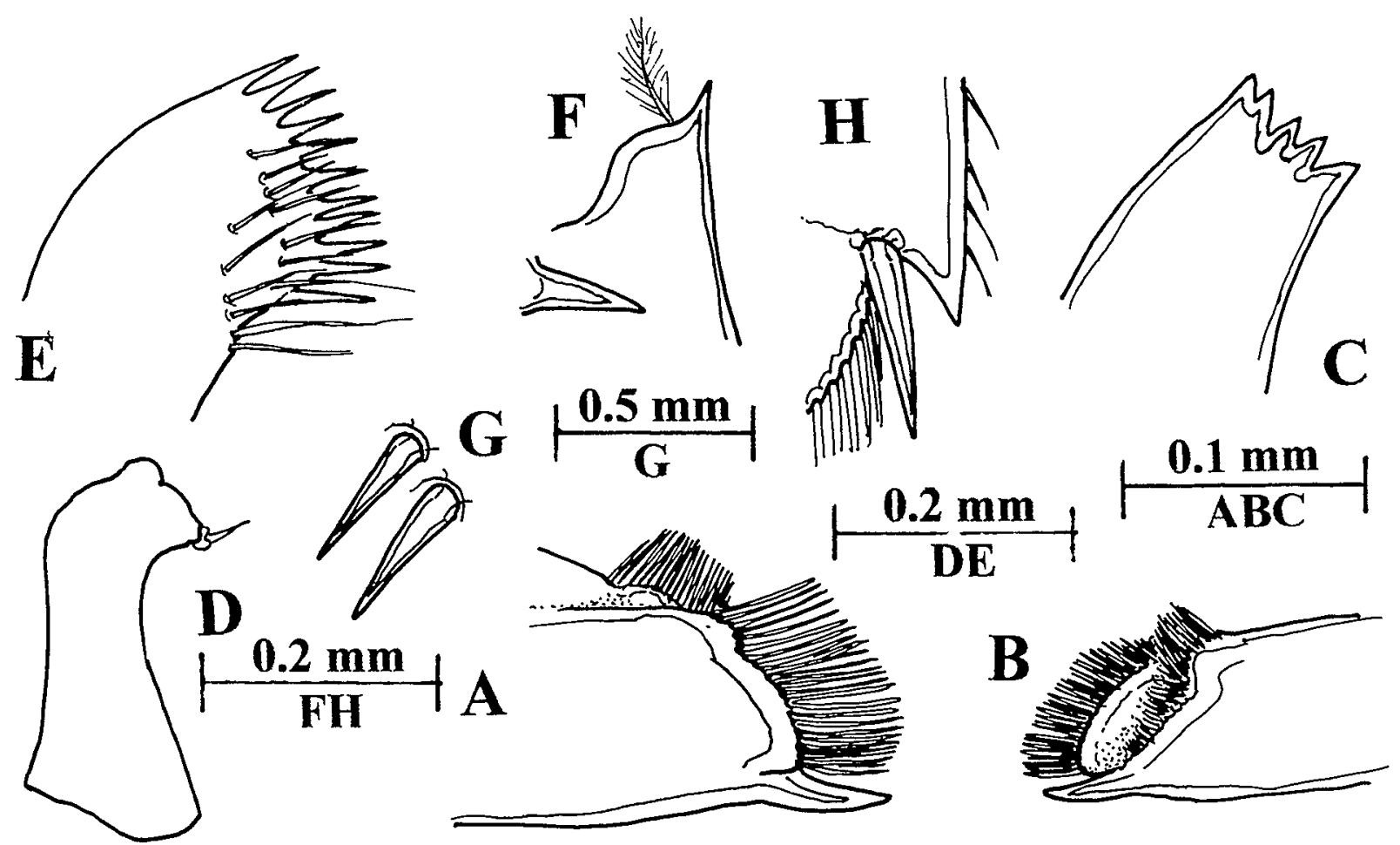

Figure 8 Periclimenaeus matherae sp. nov., holotype male. A, mandible, molar process, dorsal aspect. B, same, ventral aspect. C, same, distal incisor process. D, maxillula, palp. E, same, distal upper lacinia. $F$, antennule, proximal segment, distolateral angle; adjacent inset, ventromedial tooth, to same scale. G, dorsal telson spines, posterior spine, upper; anterior spine, lower. $\mathrm{H}$, distolateral tooth. 
about 4.3 times longer than maximal depth, tapering slightly distally, dorsal margin feebly convex, sparsely setose, ventral border straight, with short stout acute distomedial spine and much longer distolateral spine, ventral margin with 7 spines throughout length, spines larger distally, smaller and more slender proximally; carpus 0.7 of propod length, 3.2 times longer than distal width, unarmed; merus 1.2 times propod length, 3.0 times longer than central depth, unarmed; ischium about 0.85 of propod length, 2.4 times longer than distal width, unarmed; basis and coxa without special features. Fourth pereiopod similar to third, dactylar corpus without minute ventral denticulations, propod (Figure 6J) length subequal, more slender, about 4.7 times longer than depth, with distolateral and 3 distal ventral spines only. Fifth pereiopod generally similar to fourth, propod without spines, with dense distoventral setal brushes.

First pleopod. Of normal form, endopod (Figure 7F) about 3.3 times longer than width, distal third tapering, with 11 short, sparsely plumose setae, medial margin with proximal two-thirds bearing 10 short simple spiniform setae.

Second pleopod. Of normal form, appendix masculina (Figure 7G) short, about 0.12 of endopod length, bearing 3 long finely setulose spines, longest spine about 3.0 times the corpus length, appendix interna subcylindrical, about 3.0 times longer than corpus of appendix masculina, with few cincinnuli distally.

Uropod (Figure 1M). Protopodite posterolaterally unarmed; exopod 2.0 times longer than broad, lateral margin feebly convex, unarmed, sparsely setose, with stout acute distolateral tooth with longer robust spine medially (Figure $8 \mathrm{H}$ ), falling well short of distal margin of lamella, diaeresis feebly indicated; endopod of subequal length, 2.1 times longer than broad.

\section{Measurements (mm)}

Post-orbital carapace length, 3.9; carapace and rostrum, 5.8; total body length (approx.), 12.0; major second pereiopod chela, 7.5 ; minor second pereiopod chela, 3.3 .

\section{Systematic Position}

This species is most closely related to $P$. pachydentatus Bruce, 1969, but can be distinguished by the following features. Rostrum with seven teeth all anterior to orbital margin, vs six, with first tooth posterior to orbital margin, acute supraorbital tubercles present $v s$ absent, inferior orbital angle bluntly produced, $v s$ obsolete, proximal segment of antennular peduncle with very well developed ventromedial tooth, $v s$ small tooth only in this position, major second pereiopod chela with palm asperulate $v s$ smooth, third pereiopod dactyl with ventral corpus with minute denticles, vs nondenticulate, minor second pereiopod dactyl with about 45 denticle of increasing size distally, without denticulate thickened proximal region vs 50 of decreasing size distally, with denticulate proximal thickened region, third pereiopod propod with 7 ventral spines vs 3 spines only present.

\section{Colouration \\ Nọ data.}

\section{Host}

Hypodistoma deerata (Sluiter, 1895), [Ascidiacea], NTM E243, det. P. Kott. Known from NW Australia NE Australia, Northern Territory, Torres Strait, Papua New Guinea and the Philippines.

\section{Etymology}

The species is dedicated to Patricia Mather, A.O., née $\mathrm{Kott}$, a friend and colleague over many years.

\section{Remarks}

It may be noted that the mouthparts are closely similar to those of $P$. hecate (Nobili, 1904), as described by Bruce (1976: 25-27, figure 10). However, in that species, the molar process of the mandible is multidentate, and lacks the dense marginal fringes of fine long setae; the basal endite of the maxilla is simple, not bilobed, the distal scaphognathite is narrow, rather than broad, the first maxilliped has a smaller epipod, with subequal lobes, the second maxilliped has a reduced epipod (although this may be abnormal) and the third maxilliped has a row of short erect submarginal setae on the proximal medial ischial region. The upper lacinia of the maxillula has the distal spines fully fused to the lacinia as in $P$. matherae.

\section{Periclimenaeus pachydentaus Bruce, 1969 Figures 9-10}

Periclimenaeus pachydentatus Bruce, 1969: 162-163; 1974: 1583 (key); 1986: 161-167, figures. 1+1-8 (cover photo); 1993: 832-834, figure 3. - Li, 2000: 131, figure 154. - Davie, 2002: 320.

\section{Material examined}

Queensland: 1 ô allotype, BMNH 1971:153; 1 ovig. $q$ holotype, BMNH 1971.152, Gulf of Carpentaria, $14^{\circ} 12^{\prime} \mathrm{S} 142^{\circ} 48^{\prime} \mathrm{E}, 35 \mathrm{~m}, 9$ March 1929. Philippines: 1 ovig. $q$, Dr phil. Th. Mortensen's Pacific Expedition, 1913-1915, off Jolo, 25-35 m, dive, 21 March 1914, ZMUC CRU4347.

\section{Diagnosis}

Large species. Rostrum well developed, very slender, up-curved, dentition 6/0, teeth subcylindrical, proximal tooth postorbital, 


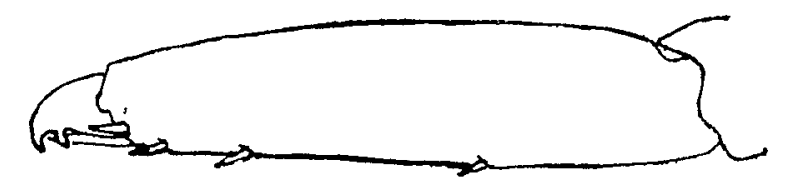

G
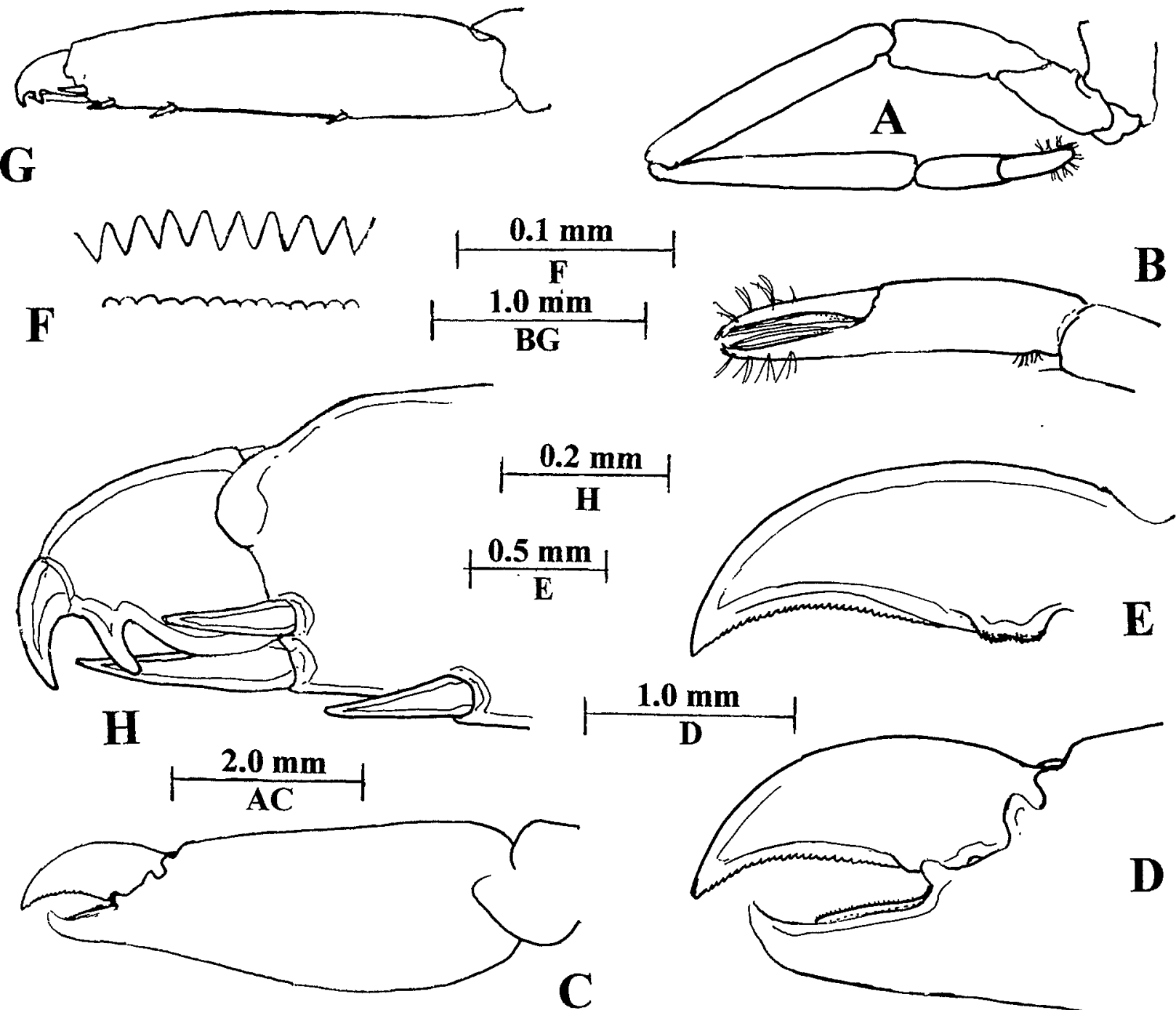

$\frac{1.0 \mathrm{~mm}}{\mathrm{D}}$

Figure 9 Periclimenaeus pachydentatus Bruce, 1969, holotype female. A, first pereiopod. B, same, chela. C, same, fingers. D, minor second pereiopod, E, same, fingers. F, same, dactylus. G, same, cutting edges of fingers, dactyl uppermost. $\mathrm{H}$, third pereiopod.

transversely broadened; supraorbital tubercles present; inferior orbital angle not produced; antennal spine large; first abdominal segment without anterodorsal lobe; scaphocerite with small distolateral tooth, first pereiopod slender, chela fingers subspatulate, cutting edges entire; major second pereiopod massive, palm smooth, dactyl with large molar process, cutting edge distally entire, fixed finger with shallow fossa, merus ventrally entire; minor second pereiopod dactyl elongate, exceeding fixed finger, cutting edge concave, finely denticulate, about 50 denticulations, fixed finger grooved, inner cutting minutely denticulate; third pereiopod dactylus short, subcircular, biunguiculate, ventral border nondenticulate, without acute basal process, propod with 2 distal spines, 3 ventral spines; uropodal exopod laterally unarmed; telson with large dorsal spines at 0.25 and 0.65 of telson length.

\section{Description}

A general description has been provided by Bruce (1969).

First pereiopod (Figure 9A). Slender, exceeding antennal peduncle and carpocerite by about 0.2 of merus length; chela (Figure 9B) slender, palm subcylindrical, slightly compressed, about 3.0 times longer than deep, with few short cleaning setae proximally, fingers about 0.8 of palm length, slender in lateral view, feebly subspatulate, broad in dorsal view, with numerous groups of short setae distally, dorsal aspect of dactylus flattened, cutting edges entire, dactylus tip with two small teeth, fixed finger with three; carpus slender, about 1.6 times longer than chela, 7.0 times longer than distal width, tapering proximally; merus subequal to carpal length, about 6.5 times longer than central width, ischium subequal to chela length, 3.0 times longer than central width, all unarmed; basis about 


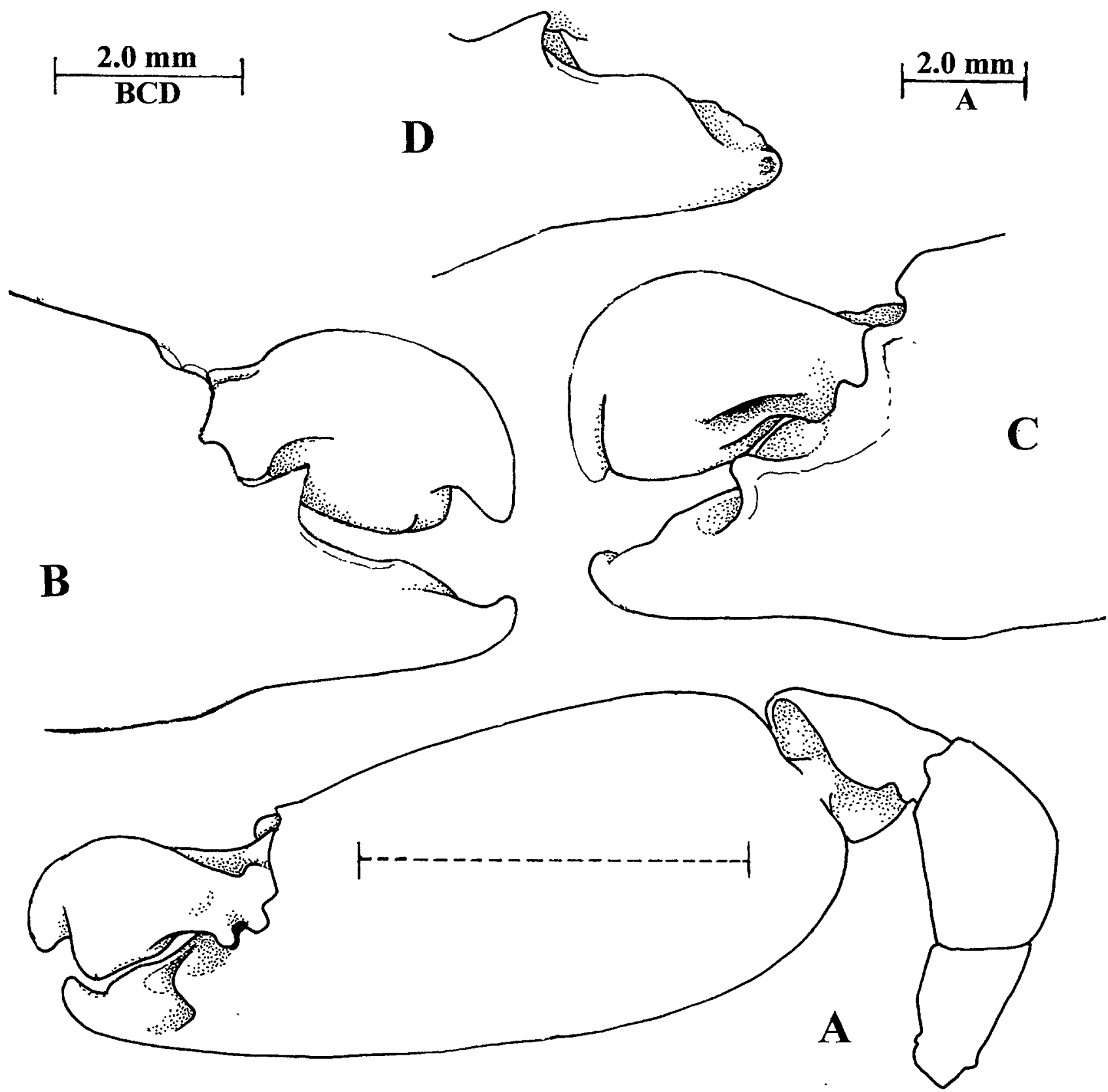

Figure 10 Periclimenaeus pachydentatus Bruce, 1969, holotype female. Major second pereiopod, chela, dotted line represents CL to same scale. B, same, fingers, medial. C, same, lateral. D, fixed finger, mediodorsal.

0.8 of ischial length, ischium more robust, without processes.

Major second pereiopod (Figure 10). Greatly enlarged, with massive chela (Figure 10A); chela about 2.6 times $\mathrm{CL}\left({ }^{\pi}\right), 1.9$ times ( $(9)$, palm smooth, glabrous, oval in section, 1.85 times longer than deep, tapering slightly distally, fingers (Figure $10 \mathrm{BC}$ ) about 0.3 of palm length, dactylus massive, 1.7 times longer than deep, dorsal margin semicircular, proximal dorsal surface with distinct groove, cutting edge with large molar process proximally, distally feebly bilobed, distally thickened with stout blunt hooked tip, preterminal cutting edge thick, entire, fixed finger about 1.2 times longer than proximal depth, medial surface with acute tooth proximally, lateral surface with blunt tooth proximally, fitting into groove on dactylus, cutting edge with shallow fossa proximally, distal cutting edge stout, expanded laterally, margin feebly crenulate (Figure 10D), cutting edge medially entire, blunt, tip stout, feebly hooked, blunt; carpus about 0.33 of palm length, as broad as long, distally expanded, excavate, tapering strongly proximally, unarmed; merus unarmed, about 0.38 of palm length, stout, swollen, 1.6 times longer than width, dorsal border concave, ventral margin straight, without tubercles or denticles; ischium unarmed, about 0.28 of palm length, 1.8 times longer than distal width, tapering proximally; basis and coxa robust, without special features. 
Minor second pereiopod ( $($ ). Not greatly enlarged, much smaller than major pereiopod, chela (Figure 9C) about 0.93 of $\mathrm{CL}, 0.48$ of major chela length, palm smooth, glabrous, 2.0 times longer than depth, at about 0.3 of length, tapering distally, fingers (Figure 9D) unequal, dactylus (Figure 9E) far exceeding fixed finger, about 0.5 of palm length, compressed, about 3.0 times longer than proximal depth, dorsal margin convex, tip acute, cutting edge concave distally, sharp, with about 50 minute acute denticles (Figure 9F), largest centrally, decreasing in size proximally and distally, proximal fourth of cutting edge thickened, covered with minute denticulations, fixed finger about 1.6 times longer than basal width, cutting edge shallowly grooved proximally, medial margin entire with blunt tooth proximally, lateral margin minutely denticulate (Figure 10F), with small rounded denticulations, much smaller than denticulations of dactylus, tip stout, hooked, acute. Proximal segments similar to major second pereiopod but smaller.

Third pereiopod (Figure 9G). Robust, exceeding carpocerite by propod and dactyl, dactylus (Figure $9 H$ ) short, stout, compressed, about 0.15 of propod length, corpus dorsal length about 1.1 times basal width, dorsal margin convex, ventral margin strongly convex, with strong recurved blunt accessory tooth distally, proximally unarmed, unguis about 0.8 of corpus length, stout, curved, 2.1 times longer than basal width, unarmed; propod (Figure 9G) about 0.3 of $\mathrm{CL}, 4.5$ times longer than deep, tapering slightly distally, sparsely setose, with stout ventromedial distal spine, longer distolateral spine, subequal to dactylar corpus length, ventral margin with preterminal spine and 2 ventral spines.

\section{Measurements (mm)}

Holotype 9, CL 6.5; major chela, 12.6; minor chela, 6.1; allotype $\$$, CL 6.1; major chela, 15.8 .

\section{Colouration}

Generally whitish with a pink tinge, densely covered with uniform minute chromatophores, female more markedly pinkish than male (from colour slide).

\section{Host}

The type specimens were found in the ascidian Hypodistoma deeratum (Sluiter), det. P. Kott, and the Philippines specimen in the same host, det. R.H. Millar.

\section{Remarks}

The original preliminary description by Bruce (1969) was unillustrated. The anterior carapace, rostrum and antennae, in dorsal and lateral view, and the telson have been illustrated by Bruce (1993).
Bruce (1986) provides a colour photo of a pair of specimens, which well illustrates the massive major chela of the second pereiopods in both sexes. In this photograph the major second pereiopod is 2.2 times the $\mathrm{CL}$ in the male and 1.5 times in the female.

The second pereiopod chelae are noted as smooth. Those of P. matherae are minutely asperulate. These minute asperities may be difficult to see. They can be more easily detected by touch, by passing the tip of a dissecting needle over the surface of the palm, when they are readily felt when present.

The type specimens are in good condition. The allotype male lacks the minor second pereiopod. The Jolo specimen show no significant differences from the type specimens.

\section{Distribution}

Known from the type locality and from Gulf of Carpentaria, Queensland, and from Hibernia Reef, Western Australia (Bruce 1981, 1992). Now also known from the Philippines.

\section{ACKNOWLEDGEMENTS}

I am most grateful to Pat Mather for the opportunity to report on these two new shrimps and for the identification of their hosts. Miranda Lowe kindly made the type material of $P$. pachydentatus available and Dr Torben Wolff, the Philippines specimen. This study was facilitated by support from the Australian Biological Resources Study.

\section{REFERENCES}

Balss, H. (1921). Stomatopoda, Macrura, Paguridea und Galatheidea. Results of Dr. E. Mjöbergs Swedish Scientific Expeditions to Australia 1910-13. XXIX. Kungliga Svenska Vetenskakademiens Handlingar 61 (10):1-24.

Berggren, M. (1997). The shrimps from the reefs off the Kimberley, Western Australia, 10. In D.I. Walker (ed.) Marine Biological Survey of the Central Kimberley Coast, Western Australia. Pp 86-90. University of Western Australia.

Borradaile, L.A. (1915). Notes on Carides. Annals and Magazine of Natural History (8) 15: 205-213.

Borradaile, L.A. (1917). On the Pontoniinae. The Percy Sladen Trust Expedition to the Indian Ocean in 1905, under the leadership of Mr J. Stanley Gardiner Transactions of the Linnean Society of London, Zoology (2) 17: 323-396.

Bruce, A.J. (1969). Preliminary descriptions of ten new species of the genus Periclimenaeus Borradaile, 1915 (Crustacea, Decapoda Natantia, Pontoniinae). Zoologisches Mededelingen, Leiden 44 (12): 159-175.

Bruce, A.J. (1970). Further preliminary descriptions of new species of the genus Periclimenaeus Borradaile, 1915, (Crustacea, Decapoda Natantia, Pontoniinae). Zoologisches Mededelingen, Leiden 44 (21): 305-315. 
Bruce, A.J. (1974). Observations upon some specimens of the genus Periclimenaeus Borradaile (Decapoda Natantia, Pontoniinae) originally described by G. Nobili. Bulletin du Muséum National d'Histoire Naturelle, Paris (3) no. 258, Zool., 180: 1557-1583.

Bruce, A.J. (1981). Pontoniine shrimps of Heron Island. Atoll Research Bulletin 245: 1-33.

Bruce, A.J. (1986). Logerende på koralrevet - rejer i samliv med mange andere dyr. Naturens Verden (5): 161-167.

Bruce, A.J. (1992). Crustacea: Decapoda Caridea. In B.C. Russell and J.R. Hanley (eds) The Biological Resources and Heritage Values of the Cartier and Hibernia Reef Systems, Timor Sea. pp.128-131. Northern Territory Museum, Darwin.

Bruce, A.J. (1993). Pontoniine shrimps from the Zoological Museum, Copenhagen. Journal of Natural History 28: 829-840.

Bruce, A.J. and Coombes, K.E. (1995). The palaemonoid shrimp fauna (Crustacea: Decapoda: Caridea) of the Cobourg Peninsula, Northern Territory. The Beagle, Records of the Museums and Art Galleries of the Northern Territory 12: 101-144.

Calman, W.T. (1939). Crustacea : Caridea. Scientific Reports, John Murray Expedition 6: 183-224.
Costa, O.G. (1844). Su due nuovi generi di Crostacei Decapodi Macrouri nota. Annali della Accademia degli Aspiranti Naturalisti, Napoli 2: 285-290.

Davie, P.J.F. (2002). Crustacea: Malacostraca: Phyllocarida, Hoplocarida, Eucarida (Part 1). In A. Wells and W.W.K. Houston (eds) Zoological Catalogue of Australia 19.3A. Melbourne: CSIRO Publishing, Australia: xii, $551 \mathrm{pp}$.

Holthuis, L.B. (1952). The Decapoda of the Siboga Expedition. Part XI. The Palaemonidae collected by the Siboga and Snellius Expeditions with remarks on other species. II. Subfamily Pontoniinae. Siboga Expedition Monograph 39a ${ }^{10}: 1-252$.

$\mathrm{Li}$, Xinzheng. (2000). Catalog of the Genera and Species of Pontoniinae Kingsley, 1878. Xueyuan Press, Beijing, pp. 319.

Nobili, G. (1904). Diagnoses préliminaires de vingt-huit espèces nouvelles de Stomatopodes et Décapodes Macroures de la Mer Rouge. Bulletin du Muséum National d'Histoire Naturelle, Paris 10: 228-238.

Nobili, G. (1906). Faune carcinologique de la Mer Rouge. Décapodes et Stomatopodes. Annales des Sciences naturelles, Zoologie (9) 4: 1-347.

Manuscript received 21 June 2004; accepted 17 February 2005 